\title{
Luke Fischer. The Poet as Phenomenologist: Rilke and the New Poems. New York: Bloomsbury, 2015. xvi + 331 pp. ISBN: 978-1-6289-2543-2.
}

\section{Kári Driscoll}

To cite this article: Kári Driscoll (2016) Luke Fischer. The Poet as Phenomenologist:

Rilke and the New Poems. New York: Bloomsbury, 2015. xvi + 331 pp. ISBN:

978-1-6289-2543-2., The Germanic Review: Literature, Culture, Theory, 91:4, 428-443, DOI: 10.1080/00168890.2016.1226064

To link to this article: $\mathrm{http}: / / d x . d o i . o r g / 10.1080 / 00168890.2016 .1226064$

巴nublished online: 02 Nov 2016.

Submit your article to this journal $\sqsubset$

Џ Article views: 11

Q View related articles $\square$

View Crossmark data ¿ 


\section{Book Reviews}

Luke Fischer. The Poet as Phenomenologist: Rilke and the New Poems. New York: Bloomsbury, 2015. xvi + 331 pp. ISBN: 978-1-6289-2543-2.

$\mathrm{I}$

n The Animal That Therefore I Am, Jacques Derrida famously recounts his experience of being caught, naked, in the gaze of his cat. In the prolonged reflection on the humananimal relationship that follows, Derrida posits that within the Western tradition there are two fundamentally distinct types of discourse regarding the animal: "In the first place there are texts signed by people who have no doubt seen, observed, analyzed, reflected on the animal, but who have never seen themselves being seen by the animal."1 In these philosophical and scientific texts, animals are only ever the objects of observation, and, as John Berger puts it, "the fact that they can observe us has lost all significance."' This first category contains almost all of Western philosophy and science. In the second category we find primarily texts by "poets and prophets" (14), and, indeed, as Derrida affirms, "thinking concerning the animal [la pensée de l'animal], if there is such a thing, derives from poetry. There you have a thesis: it is what philosophy has, essentially, had to deprive itself of. It is the difference between philosophical knowledge and poetic thinking [une pensée poetique]" (7). Poetic thinking, by implication, is, in some sense, synonymous with "la pensée de l'animal," which, in turn, would be a form of thinking that has taken account of the fact that what we call "the animal" can look at $u s$ and, "in a word, without a word, address" us (13). Since philosophical thinking is essentially opposed to this poetic thinking of the animal, Derrida is hard-pressed to find among the philosophers an adequate representative for the latter category. The question then must be: How might philosophy become more like poetry?

This is precisely the question at the heart of Luke Fischer's The Poet as Phenomenologist. Fischer, a poet in his own right, argues that "the art of poetry can address certain philosophical problems more adequately than philosophy itself" (xi) and that, therefore, "philosophy must become more poetic and concern itself with poetry" $(285 \mathrm{n} 140)$ if it is to

\footnotetext{
${ }^{1}$ Jacques Derrida, The Animal That Therefore I Am, ed. Marie-Luise Mallet, trans. David Wills (New York: Fordham University Press, 2008), 13 [translation modified].

${ }^{2}$ John Berger, "Why Look at Animals?" About Looking (New York: Vintage, 1991), 3-28 (16).
} 
overcome the pervasive "crisis" (1) in which it finds itself. This crisis, Fischer argues, has its roots in the problem of metaphysical dualism, and in the fact that the various monistic philosophies that have sought to overcome it fall short of an adequate account of lived experience. Only phenomenology, in Fischer's view, can do this, whereby experience is conceived as a "non-dualistic disclosure," an "unconcealment of Being" (25). As such formulations suggest, Fischer's approach owes much to Heidegger, particularly in his privileging of poetry as "a saying of being" (226), but Merleau-Ponty's phenomenology of perception is also a major reference point. As the title of his book indicates, however, Fischer's principal claim is that Rilke himself was a phenomenologist, whose " "philosophy' is inherent to the poetry and as poetry" (96). The ultimate aim of Fischer's study is thus "to make explicit the internal philosophical significance of Rilke's vision and poetry" (96).

In the opening chapter, Fischer lucidly lays out the problem of dualism and the phenomenological framework of his study, and in chapters two and three he proceeds to examine the parameters for what he terms Rilke's "twofold seeing": an integrated, non-dualistic vision that facilitates "a privileged disclosure of things, in which inner and outer, the invisible and the visible, activity and passivity, are revealed as two aspects of a single whole" (10). Rilke's poetry is singularly preoccupied with the problem of seeing and being seen, with the "question of the animal" and the animal's gaze. As Rilke writes in the celebrated opening of his eighth Duino Elegy (1922), animals see "the Open," which is Rilke's term for the world as an integrated whole, beyond the limiting constructs of human language and signification. Human beings, locked in their dualistic worldview, can only hope to glimpse the Open as it is reflected in the gaze of an animal. ${ }^{3}$ Fischer concentrates on Rilke's middle period (ca. 1902-10), during which Rilke was engaged in a project of "learning to see," which can be regarded as an attempt to unlearn the dualistic worldview imposed on him from an early age and to learn to see the world like an animal — or a child, whose conception of the world is still pre-dualistic (Fischer 78-90). This process was fueled by his encounter with the work of two visual artists, each of whom would have a profound impact on his poetic craft: Auguste Rodin and Paul Cézanne. Fischer devotes a substantial portion of his book (96-168) to a careful analysis of these two artists' artistic praxis, the modes of seeing that informed them, and, above all, Rilke's own reflections on their work and its relation to his own.

Rilke's "twofold" mode of seeing always implies a reciprocity or "active-passivity" (105), whereby "the act of seeing assumes a gesture of passivity or suffering, as though to see simultaneously involved being seen by that which is seen" (193, original italics). This relationality is important because it allows Fischer to challenge interpretations of Rilke's poems - particularly the Dinggedichte - that have sought to read their central figures exclusively as passive objects of Rilke's gaze and, ultimately, as metaphors or symbols of the poet himself - a tendency that Fischer dubs "hermeneutic violence" (237). By contrast, through his emphasis on the phenomenal basis for Rilke's poetry, Fischer insists that the poems are

\footnotetext{
3"We know what is really out there only from / the animal's gaze." Rainer Maria Rilke, The Selected Poetry of Rainer Maria Rilke, ed. and trans. Stephen Mitchell (New York: Vintage, 1989), 192-93.
} 
grounded in the things themselves (208), whose essence is poetically disclosed through an encounter with their peculiar givenness. This is an important and legitimate intervention. Fischer is right to insist that iconic poems such as "The Panther," "The Gazelle," or "The Swan" are, first and foremost, records of an engagement with these animals and their particular modes of being-in-the-world. At the same time, however, the mythical and symbolic valences attached to these and other animals are also of central importance. They are, to borrow a phrase from Donna Haraway, "material-semiotic nodes," the material is likewise to reinstate a form of dualism. Fortunately, Fischer is aware of this and rightly observes that perception never occurs in a vacuum, but rather always within a hermeneutic horizon (52-53). Hence, a gazelle is always already both a physical, individual creature and a creature of the literary tradition, both natural and cultural. Moreover, Fischer convincingly argues that the gazelle could serve as a symbol of love, beauty, and gentleness in the poetic tradition only "because its phenomenality manifests these qualities" (245). Nevertheless, it is not always clear what the status of the irreducible haecceity of the individual animal is in relation to the "ontological essence" (191) of its being that is disclosed "in each case" (184). Fischer is quite vague and even self-contradictory on this point, claiming, for instance, that Rilke's "twofold" seeing enables him to participate in a dog's "dogness" "in a real sense and not in the sense of an abstract universal" (191). But what does that mean, exactly?

Things get yet more problematic when Fischer insists that Rilke's poetry not only represents an attempt at overcoming dualism, but actually succeeds in doing so (191). To support this claim, Fischer must argue that concepts such as "Weltinnenraum" and "das Offene" are not metaphysical postulates but rather objects of Rilke's own personal experience (206). In other words, we are asked to believe that Rilke's "exceptional" perception allowed him to perceive firsthand the fundamental unity of thinking and Being, inside and outside, and so on. The problem is that although Rilke unquestionably aspired to such a worldview, he also repeatedly insists on the difference between "us" (humans) and "them" (animals and the natural world). The Duino Elegies are elegies also for the lost integral plenitude of the world, a loss that is made all the worse by the awareness that animals, because they lack language, are not cut off from "was draußen ist." Rilke's holistic worldview is thus predicated on an insurmountable anthropocentrism, and hence a dualism: a melancholy or reluctant form of dualism, perhaps, but a dualism nonetheless.

This is something Rilke has in common with other poets of the Sprachkrise-a term that is notably absent from Fischer's book. Indeed, Fischer makes almost no attempt to place Rilke's poetry or the problem of dualism within its historical or cultural context. (The word "modernism" does not appear in the index, for instance.) This is no doubt symptomatic of the philosophical framework for the study, as well as Fischer's conviction that Rilke has already solved the problem of dualism. Thus, in his conclusion, Fischer reiterates his call for philosophy to become more like poetry, even as he avers that he has not considered to

\footnotetext{
${ }^{4}$ Donna J. Haraway, When Species Meet (Minneapolis: University of Minnesota Press, 2008), 4.
} 
what extent philosophy may itself have attempted to bridge the gap between philosophical and poetic language (301), before directing the reader somewhat arbitrarily to Derrida's essay "White Mythology" from 1971. The four decades of philosophical discourse since then are not taken into consideration, ostensibly because this would have required an additional monograph. Even so, it would have been important and valuable to reflect on what it means to read Rilke as a phenomenologist today, particularly in relation to the recent critiques of that school mounted by new materialism and object-oriented ontology, respectively, namely of its positing of relata (individual entities) as preexisting relation, ${ }^{5}$ and of its latent idealism and anthropocentric "correlationism."6 Despite these shortcomings, The Poet as Phenomenologist is a valuable addition to Rilke scholarship in English, particularly for its careful and comprehensive analysis of Rilke's poetics of vision.

KÁRI DRISCOLL Utrecht University

\footnotetext{
${ }^{5}$ See Karen Barad, Meeting the Universe Halfway: Quantum Physics and the Entanglement of Matter and Meaning (Durham: Duke University Press, 2007), 132-85.

${ }^{6}$ See Graham Harman, Guerilla Metaphysics: Phenomenology and the Carpentry of Things (Chicago: Open Court, 2005), 49-53; and Quentin Meillassoux, After Finitude: An Essay on the Necessity of Contingency, trans. Ray Brassier (London: Continuum, 2008). "Correlationism" is a term coined by Meillassoux to describe the philosophical view that "we only ever have access to the correlation between thinking and being, and never to either term considered apart from the other" (5). For Meillassoux this is the problem to be overcome, whereas for Fischer, a "coincidence of Being and thinking" (7) is precisely what is needed to transcend metaphysical dualism.
} 
Nina Bodenheimer. Heinrich Heine und der Saint-Simonismus (1830-1835). Stuttgart: Metzler, 2014. 194 pp. ISBN 978-3-476-02521-0

There has been a lot of speculation around Heine's engagement with the Saint-Simonists, a sect whose allure consisted in propagating a vision with a peculiar mix of progressive proto-socialist and oddly authoritarian tenets that had become all the craze in the 1820s and 1830s, inspiring progressive liberals such as the Varnhagens. At the same time, the SaintSimonist's reach went far beyond this, attracting also secret admirers on the reactionary side of the political spectrum such as Metternich. The Saint-Simonists were among the very first and, initially, the most hospitable group of people Heine met upon his arrival in Paris in 1831, or so at least it seemed; these encounters produced some of the most enduring friendships Heine made in France. No wonder, then, that the echoes and resonances to Saint-Simonist ideas and motives that run through Heine's writings, both prose and poetry, represent a rich and complex weave of allusions, themes, and motives.

Nina Bodenheimer's study is a welcome in-depth exploration of the often complicated motivations and background stories that brought Heine and the Saint-Simonists together, if only for moments of strategic alliance. Attracted by the appeal of the Saint-Simonists' inclusive and progress-oriented vision, their initially welcoming attitude played a crucial role in making Heine feel at home in his new city and culture of choice. Bodenheimer examines this question in the context of the wider issue of the French-German transfer of culture and thought in which Heine moves. Her study thus allows us to grasp Heine's critical intervention more precisely as a cultural and political project that, in turn, allows for a more precise understanding of the role that the brief but intense encounter with the Saint-Simonists had. Bodenheimer's diagnosis of this mutual misunderstanding highlights the complicated backand-forth movement that determined the French-German transfer of ideas that resulted in an overdetermined reciprocal impact from which both sides would emerge profoundly informed by the other. The French-German complex of interaction went so deep that the fixation on the particularities of German and French cultural identities comes into focus as a function of this intensely transferential interaction. In this context, the Saint-Simonists represent an illuminating case study for how profoundly German-French intellectual traffic relied on German thought to form French visions and on French politics to inform German thought. The emergence of modern national identity was thus informed by the hyper-binary distinction that had become the function of this peculiar mirror effect across the line of the Rhine.

Seen this way, the critical role of Heine's trajectory assumes new importance. As Hegel and Lessing played a crucial, near-foundational role in the thought of the Saint-Simonists, Heine's writings in the 1830s, especially his two historical works The Romantic School and On the History of Religion and Philosophy in Germany respond critically to the problematic appropriation of these thinkers as well as German thought more generally. Examined in this context, Heine's critical correction, as Bodenheimer calls it, of the reception of Hegel and Lessing highlights the way in which their thought becomes the cultural capital on which the French-German economies both agree and grow apart.

If Bodenheimer's notion of Heine as student and follower of Hegel might lead her toward assuming a too subservient relationship to the master thinker, the evidence she musters suggests otherwise. Hegel's unquestionably recurrent presence in Heine should be seen less 
as a sign of identification than as a steady point of reference in relation to, and often against which, Heine so pointedly launches his comments. From Emma Lazarus to Jürgen Habermas, Hegel has been viewed as a central influence for Heine. But this came at the cost of ignoring the particular way in which Heine's writings in prose and poetry challenge and subvert at every point and angle the overpowering force of Hegelian philosophy. Heine's pointedly nonphilosophical approach targeted Hegel as the dominant reference point, the man who called the shots in Berlin and, subliminally, as Bodenheimer reminds us, in Paris as well. Even Marx remained spellbound by the force-field of Hegelian philosophy even and especially where he sought to topple it. But while with Marx the question remains as to whether he ever got beyond Hegel or whether the desire to do so would subject him even more so to Hegel's thought, Heine kept cautiously aloof, investing his literary stage performances of encounters with Hegel with carefully crafted false bottoms of humor and distancing reflections.

The most important result of Bodenheimer's study is without a doubt the clarification of Heine's temporary investment in the Saint-Simonists followed by a quick withdrawal. From this exchange Heine took the motto of the rehabilitation of matter and flesh and the vision that society should be organized along the lines of "everybody according to their capabilities and needs." What had seemed like a sound recognition of the body and the senses by the Saint-Simonists presented the central appeal for Heine. But for Heine, their authoritarian claims would cancel out the emancipatory impulse that the rehabilitation of the senses had for Heine. In the end, the Saint-Simonists embraced the kind of bad metaphysics Heine so deeply despised.

While the Saint-Simonists self-consciously claimed independence from Spinoza, Bodenheimer's study suggests a crucial, if indirect, connection via the Saint-Simonists' reception of Hegel and Lessing. If the central role Spinoza plays in the emergence of Hegelian thought is profoundly linked to German Idealism, as Bodenheimer reminds us, Lessing's Spinozist notes in the "Education of Mankind"- - a text that, as her study shows, assumed a key role in the development of Saint-Simonism—suggest a subliminal but decisive affinity with Spinoza's thought explicitly denied by Prosper Enfantin, the self-appointed spiritual head of the sect. It is no coincidence that he would be little amused by Heine's provocative move at the heart of his rewriting of modern intellectual history that declared Spinoza the key figure of modern European thought.

While some camps of Heine scholarship have been bedeviled by the idea that Heine was a closet Saint-Simonist, Bodenheimer demonstrates that his enthusiasm lasted only a year or two and was even then qualified. But more importantly this study suggests that the derivative nature of Saint-Simonism demonstrates rather the opposite-that Heine's turn to Spinoza signaled a subtly coded critique of what the sect increasingly showed to lack: the substance behind the suave words of high-handed spiritual direction. If Bodenheimer does not draw this conclusion in explicit terms, her study suggests so much, if it is contextualized in the larger picture of the intellectual history in which she squarely places her argument. Bodenheimer reminds us that, despite the overwhelming research on Heine, there are still new insights to be gained. 
Axel Honneth. Die Idee des Sozialismus: Versuch einer Aktualisierung. Berlin: Suhrkamp, 2015. 168 pp. ISBN: 978-3-518-58678-5.

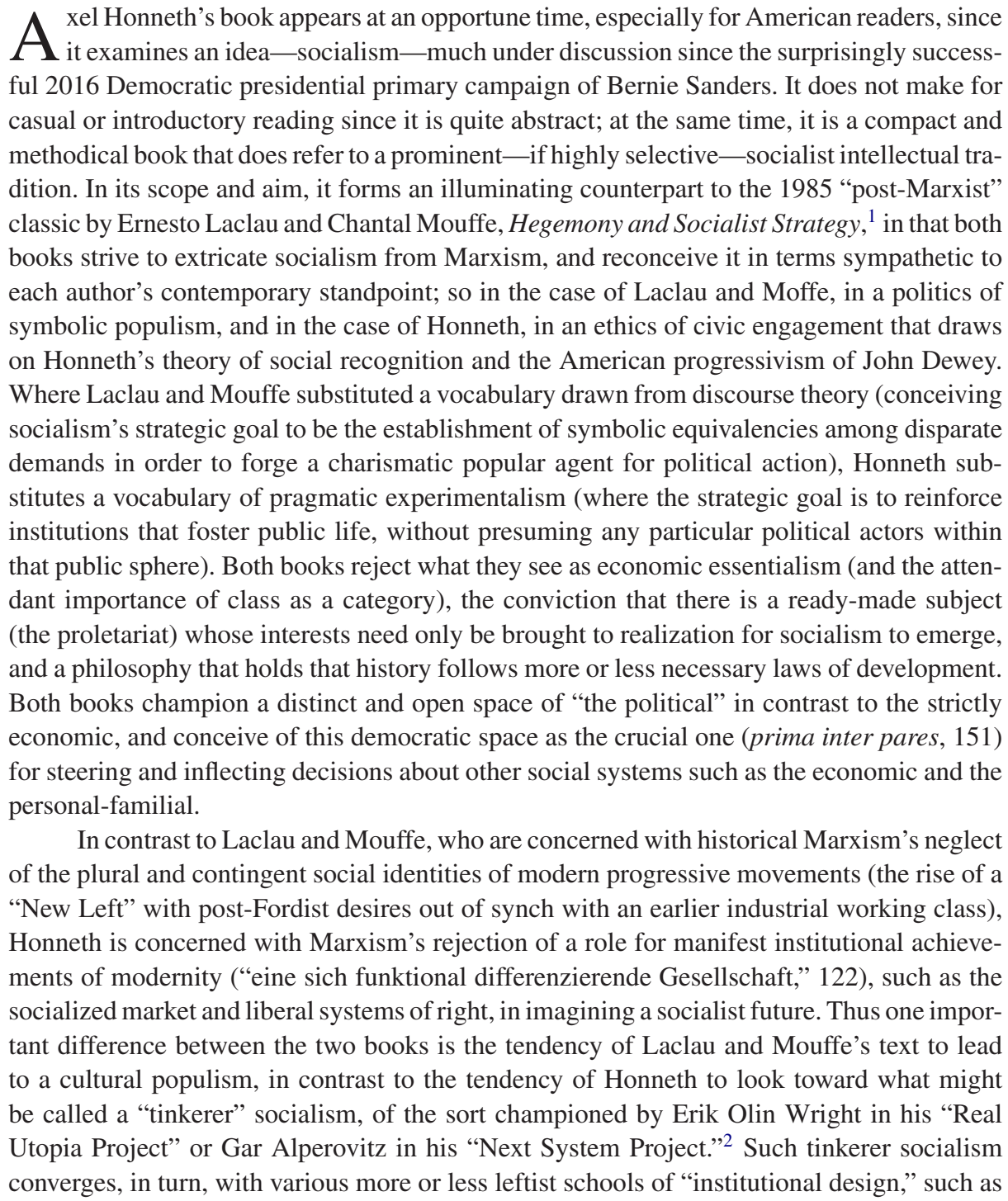

\footnotetext{
${ }^{1}$ Ernesto Laclau and Chantal Mouffe, Hegemony and Socialist Strategy: Towards A Radical Democratic Politics (London: Verso, 1985).

${ }^{2}$ Erik Olin Wright, Envisioning Real Utopias (London: Verso, 2010); Gar Alperovitz, What Then Must We Do? Straight Talk About the Next American Revolution (White River Junction, VT: Chelsea Green, 2013).
} 
those that have sprung up around the work of Elinor Ostrom (commons governance), Yochai Benkler (networked producer democracy), and Roberto Unger (left alternative program). ${ }^{3}$ These thinkers conceive of institutions in terms of their dynamic functions, which have the potential to foster communication and innovation, rather than in terms of socially predetermined interests and necessary antagonisms. Indeed, a strong feature of these thinkers is a rejection of the Marxist focus on crisis in favor of a normative reconstruction of public demands and the pragmatic construction of responses.

Honneth's argument can be put succinctly, in his own play on Marx's famous formulation of the dynamic of historical materialism as a revolutionary contradiction between "forces of production" and "relations of production." Honneth maintains that the "productive force" of the socialist idea has to be separated from the "theoretical relations" of Marxism that, because they are anchored in the analysis of nineteenth-century "Manchester capitalism," only hinder the idea's contemporary potential (85). He sees this conflict between the productive force of an idea and its historical attachment to an outmoded historical metaphysics not as an occasion for doing away with history and translating the socialist idea into a set of pure normative propositions (a move he attributes to "analytical Marxists"). Rather, he sees it as an opportunity to correct fundamental "mistakes" in the historical development of the socialist idea, mistakes that led it away from what he considers its basic content, namely, a normative orientation toward "social freedom." With those historical burdens lifted, socialism has the potential to again become an idea that speaks to the general public about its possible future in immediate practical terms.

The core idea of Honneth's reconstructed socialism, "social freedom," consists in the type of freedom that is consistent with the other two ethical imperatives of the French revolution, equality and solidarity—in contrast to liberalism's characteristic "negative freedom" to do with one's property as one wants so long as one does not interfere with others' similar freedom to dispose over their property. The contradiction between that sort of possessive individualist freedom and the other two principles of the revolution, a contradiction that quickly became apparent with the rise of nineteenth-century capitalism, was the main target of early socialist thought, as expressed in the work of Saint Simon, Proudhon, Fourier, Owen, and others. In its broadest sense, social freedom is just the freedom for self-realization in a process of mutual association and recognition. It is stronger than the merely epistemological "public use of reason" proposed by Kant as key to the process of enlightenment. It is also stronger than a concept of solidarity merely as an instrumental precondition for individual freedom. What puts social freedom at the center of the socialist idea is its orientation toward "mutual participation and sympathy" ("wechselseitige Anteilnahme," 48), such that all are concerned for the self-realization of each other. Individual freedom is still indispensable to the idea, but in contrast to liberal individualism, such freedom depends on fostering participation in the community.

\footnotetext{
${ }^{3}$ Elinor Ostrom, "Beyond Markets and States: Polycentric Governance of Complex Economic Systems," American Economic Review 100 (June 2010): 641-672; Yochai Benkler, The Wealth of Networks: How Social Production Transforms Markets and Freedom (New Haven: Yale University Press, 2006); Roberto Mangabeira Unger, The Left Alternative (London: Verso, 2005).
} 
The fateful (if not fatal) mistake of socialism, according to Honneth, was to neglect the revolutionary achievement of the enunciation of basic human civil rights ("Rechtsblindheit," 127). Instead of wedding itself to the defense of those rights, socialism all too easily (Honneth cites Marx's 1843 essays "On the Jewish Question" and "Contribution to the Critique of Hegel's Philosophy of Right") swept aside concern with the state as a site for the formation of public will. Instead of hitching its star to the defense and expansion of rights, socialism dug into the exclusively economic sphere of production as the redoubt for class struggle. With that fundamental neglect of the democratic state, socialism saddled itself with its three primary burdens - seeing the economy as the exclusive sphere for the struggle for social freedom, yoking itself to revolutionary agents assumed to already exist in the economic sphere (despite empirical evidence to the contrary), and expecting historical laws to propel this nascent agent (the proletariat) to victory.

Honneth's cure for what ails socialism is to appeal to "the public," not as a constituted collective agent, but as a mode of ethical interaction among individual citizens oriented toward a common purpose and mutual recognition, in order to legitimate institutionbuilding that fosters unhindered communication and non-coercive community. He characterizes the public with an organic analogy, seeing it as the central steering instance for bringing autonomous bodily organs together in a way that sustains the overall organism. Through his appeal to public-minded citizenry, Honneth aims to return socialism to its central idea of social freedom, which allows it to continue with its founding project of opposing the inequality of wealth and power that results from the dominance of individualistic freedom over norms of solidarity and equality.

Arriving, in the concluding chapter, at Honneth's "corrected" idea of socialism, I could not avoid the feeling that his achievement was to substitute a vague ethical appeal to social justice and public participation for at least three distinct traditions of the left-its workingclass collectivism, its mass-membership parties, and its nonconformist social movements. To be sure, the left remains the loyal voice for maintaining public institutions-public education, health care, welfare, social wages, and infrastructure-and, in its efforts to do so, it appeals as much to a Dewey-esque populism as it does to any tradition of labor militancy. But the hard problems of the left today remain unaddressed by Honneth's reconstructed idea. To take two examples from our contemporary headlines-the sovereign debt crisis of Greece and the EU refugee crisis-potential solutions to these social and economic crises seem to have little to do with "welcome cultures" and communicative transparency. To be sure, public figures, such as the leftist former Greek Minister of Finance Yanis Varoufakis, are promoting a vision of reformed EU institutions under a slogan of "transparency" (which apparently means livestreaming EU meetings, publishing minutes in timely fashion, and uploading documents to the web-rather like my faculty council). But the obvious tragedy of SYRIZA has everything to do with the ability of capital to move quickly to bankrupt organizations that do not play by its rules (i.e., so-called capital strikes, where capital withholds investments due to behaviors unfriendly to investors). Socialism, under any definition, would seem to require some way to think about a countervailing strike potential whose militancy would go beyond appeals to a diffuse and largely dispirited public. Likewise, without class politics, Europe's welcome culture will all too easily tip into a distributional struggle fought out at the bottom of the wage and power scale. Capital counts on the far right to scare potential 
left forces to play consensus politics lest the right hegemonize popular discontent into xenophobic extremes. With the staggering accumulated inequality of wealth and power in today's developed world, an appeal to public ethics, while high-minded and, indeed, important as far as it goes, suggest little about the sort of strategic alliances—and social weapons-socialism has to forge if it is to continue to be the standard-bearer of social freedom.

So what is missing in Honneth's book? Without accounts of crisis and ideologywhich have been crucial elements of Marxism's theoretical renewal (especially in the work of Alain Badiou, Jacques Rancière, and Slavoj Zizek ${ }^{4}$ ——socialism, arguably, loses sight of the critical event necessary to focus its proponents on what will inevitably be a political task demanding enormous force of will (one need only think of the looming cataclysms of climate change). Despite my everyday sympathy for Honneth's emphasis on a democratic public spirit that is warm, but roomy enough to accommodate real liberal freedoms in its social project, I fear it is an all-too-vulnerable creature of the ethical imagination, a likeness of a working class that had, following World War II, transformed itself into a "middle" class, and now, since the advent of neoliberalism, is confronted with a rapidly vanishing future. In this context it is useful to recall the recent debate between Wolfgang Streeck and Jürgen Habermas over the democratic potential of the EU currency union-which Streeck, in contrast to Habermas and Honneth, sees as nonexistent. While the debate demonstrates room for argument based on shared normative orientations guided by a goal of social freedom, a simple remark by Streeck gets to the heart of my problem with Honneth's updated (or watered down) socialism: "we cannot do democratic theory without political economy."5

BENJAMIN RoBINSON Indiana University Bloomington

\footnotetext{
${ }^{4}$ For the difficulty of accommodating the diverse streams of the socialist left in Honneth's "idea," it is instructive to see the nearly unbridgeable gulf between his idiom and that of Rancière in Axel Honneth and Jacques Rancière, Recognition or Disagreement: A Critical Encounter on the Politics of Freedom, ed. Katia Genel and Jean-Philippe Deranty (New York: Columbia University Press, 2016).

${ }^{5}$ Wolfgang Streeck, "Small-State Nostalgia? The Currency Union, Germany, and Europe: A Reply to Jürgen Habermas," Constellations 21.2 (2014): 213-21, 218.
} 
Sonja E. Klocke. Inscription and Rebellion: Illness and the Symptomatic Body in East German Literature. Rochester, NY: Camden House, 2015. 258 pp. ISBN: 9781571139337.

S ynthesizing historiographic research and literary analysis, Sonja E. Klocke's timely monograph offers a powerful interdisciplinary reading of the relationship between (East) German literature, social discourse, and the politics of health. First and foremost, the study illustrates the role of literature as witness to a synecdochal relationship between individual wellbeing and the national body politic in the GDR. Using meticulous historiographic research to reveal the ideological positioning of the medical patient as a passive, disempowered object whose health was considered Staatseigentum, and analyzing various literary representations of the "symptomatic body," Klocke negotiates the intersections between literature and society. In this, she builds on and contributes to Foucauldian readings of GDR discourse as a controlled space, familiar from the work of David Bathrick and others. The study's interdisciplinary combination of sociohistorical and poetic/aesthetic perspectives is one of its main strengths and distinguishing features, reflecting how the literary text, able to access both public and private discourses, has offered counternarratives to hegemonic discourse about health and wellbeing both before and since 1990 .

Crucial, too, is the reading of the symptomatic body as a literary motif generated by the specific cultural and social context of the GDR. While the concept of the body as a mirror for the tensions of social discourse is far from solely East German (Oskar Matzerath and Gregor Samsa spring to mind), Klocke makes a good case for the GDR, with its restricted public discourse and highly politicized medical institutions, as a context in which literature might be used as an alternative forum for the displaced discussion of social questions. In particular, it is (disruptive) female bodies that have captured Klocke's attention as most often bearing marks of social violence: the study's convincing account of the politicization of health and its depiction in the literary text is supported by feminist and queer theories of othering that draw neat parallels to discourses of self and other that have informed representations of the GDR in post-1990 German literature. The symptomatic body is thus not only emblematic of a literary tradition formed in the GDR but also of narratives that, since Reunification, have continued to have relevance as the body of the individual inscribed by society and history remains a means of archiving, accessing memory, and identification. Beyond drawing attention to the discursive power of literature, then, Klocke's emphasis on the ongoing relevance of the symptomatic body in recent writing in German is also a call to acknowledge the legacy of GDR literature beyond 1990.

By taking Christa Wolf as a central figure of influence and starting point for this investigation, the study is a welcome addition to the current revival of scholarly interest in Wolf and offers a new reading of continuities between the author's earlier and later writing. Wolf is convincingly read as a historiographer of the GDR, and a detailed analysis of Nachdenken über Christa T. focuses attention on how, for Wolf, the symptomatic body is definitively socialist: sickness is a consequence of the body being forced into "Anpassung" with false norms such as female sacrifice or passive patient behavior. Crucially, though, Christa T. is also a figure of hope for the future, as her bodily suffering later serves to purify her as a socialist model when she accepts this suffering as service to the state. Meanwhile, in Wolf's 
post-Reunification text Leibhaftig the symptomatic body continues to signify the superiority of socialist values, as the protagonist relies on her symptomatic suffering as a resource for coping with crises of memory and identification: through her pain she is able to confront and break free from her past by identifying with the GDR's anti-fascist heroes. Following Wolf's public fall from grace in the early 1990s and the marginalization of GDR identities in the communicative memory of the new German state, Leibhaftig is read as the enactment of a healing process necessary for Wolf's return to the literary body politic.

Through the suffering and healing of the symptomatic body, then, Wolf is able to claim a new position of authority for the post-socialist writer in the capitalist context: the critical role of the author as contemporary witness and historiographer. The symptomatic body thus emerges as a key indicator of continuity in her writing and an argument against any assumption that 1990 marks a caesura in her work or her relationship with socialism. While Wolf is critical of the disempowered position of the patient in the GDR, of modern medicine's reliance on technology, and of treatments that suppose a division between mind and body, the study shows how both her pre- and her post-1990 writing can also be read emphatically as a plea for the superiority of socialist principles. Wolf fundamentally rejects the abjection of the GDR and of politically engaged literature, and the symptomatic body is read convincingly as evidence of a trajectory from her position as committed socialist writer in the socialist state to a new position as social(ist) critic in a capitalist context.

While Wolf sees something inherently socialist in the significance of the symptomatic body even after 1990, post-Reunification writing by a younger generation of East German authors demonstrates the salience of the motif in writing that does not share Wolf's political commitment to socialism. Klocke shows in detail how writers such as Kathrin Schmidt, Kerstin Hensel, and Thomas Brussig explore the physical imprint of historical moments on individuals, using the bodily impact of historical and political power to demonstrate continuity between the GDR and fascist Germany or the Berlin Republic. While they critically confront the realities of medical care and politicized bodies in the GDR, their stories also show failings in a post-1990 FRG social system that has been unable to provide for those who were better supported in the GDR, such as transsexuals or pregnant women. Here, literature continues to act as an alternative historiographer, just as in Wolf's writing; a significant difference from Wolf's work is that these authors focus on articulating typically underrepresented experience by introducing explicitly disruptive bodies, undermining heteronormative and binary traditions of sex and gender as well as a norm of ethnic homogeneity. Rather than identifying with victims through their suffering or offering an assessment of political ideology, they use symptomatic bodies to counter the communicative memory of the GDR state circulated via the hegemonic discourses of post-1990 Germany.

As Klocke notes, it is highly significant that these younger writers show how the exploration of social concerns can continue to be displaced from public discourse into literature. While reflecting on the failings and failure of the socialist project, these texts also show the endurance of the GDR's control mechanisms and ideologies beyond the apparent caesura of 1990. In Hensel's Lärchenau, thanks to the rejection of the GDR's social institutions in favor of traditional power structures after 1990, the sinister Dr. Konarske finds a new degree of control over his wife Adele and is able to further his violent and invasive research with the help of the West German Professor Dickescheidt; in Antje Ravic Strubel's Sturz der Tage in 
die Nacht, the protagonist's overwhelming physical reaction to the reappearance of a Stasi officer from her past adds impact to her realization that, in the legal framework of the FRG, it is she who will be punished for her actions and not he for his. Thus the FRG is shown to be just as forceful as the GDR in its expectation of conformity to societal and political norms. Successfully implemented in but not exclusive to the GDR, specters of control in post-1990 Germany represent the continuing presence of the totalitarian or ideological "monsters" in society that also concerned Christa Wolf. By showing how the bodies of their protagonists enact anxieties about experience, these writers express concern that Germany may be unable to confront its past if social discourse does not recognize the role of the body and its somatic relationship to memory. While they do not share Wolf's political values, these younger writers subscribe to a continuing tradition of exercising social commentary in the realm of fiction, demonstrating the enduring relevance of symptomatic bodies in societal discourses and a legacy of discursive strategies that emerged in the GDR and have not simply fallen out of use since 1990.

Whether fundamentally socialist or more focused on destabilizing hegemonic discourses about the GDR as "past" or "other," the texts studied in Klocke's volume are read convincingly as a coherent body of work that understands literature as a source of alternative histories and narrative. There is a strong sense throughout the study of the continuing importance of this act of witness as resistance to hegemonic accounts of history and identity, and this understanding of literature as historiography "from below" has relevance far beyond the GDR and German studies. Perhaps most importantly from the perspective of Germanistik, by showing how Wolf and other writers continue to challenge hegemonic discourses through their treatment of symptomatic bodies, Klocke demonstrates the continuing legacy of the GDR's literary tradition in post-1990 Germany and offers a new paradigm for reading its impact on contemporary East German literature.

CAROLine Summers

University of Leeds

Leif Weatherby. Transplanting the Metaphysical Organ: German Romanticism Between Leibniz and Marx. New York: Fordham University Press, 2016. 472 pp. ISBN: 978-0823-269-402.

I eif Weatherby's Transplanting the Metaphysical Organ: German Romanticism Between Leibniz and Marx is not just a significant scholarly contribution to the study of German Romanticism but also an intellectual tour de force in its own right. Transplanting the Metaphysical Organ uncovers a rich conceptual and discursive history that runs throughout German philosophy, science, and literature from Leibniz to Marx in order to show how a specifically romantic metaphysics emerges from an intensified engagement with the concept of the organ.

Although the organ — as organon - has been a part of Western philosophical and scientific discourses since antiquity, Weatherby argues convincingly that this term becomes subject to discursive multiplication and reconfiguration in the late eighteenth century, ultimately 
being imbued with a metaphysical, aesthetic, cosmological, and political weight lacking from its earlier iterations. Weatherby takes his point of departure from the Aristotelian conception of the organ, or "that functional part-in any order, natural or human-which is so organized as to bring about a specific effect within a field of possibility its own specificity circumscribes" (18). The romantic discourse of the organ, while shifting emphases according to different contexts and different thinkers, inherits from this Aristotelian framework a conception of the organ as a localized horizon of effectiveness: any functional part or assemblage of parts that enables a movement from potentiality to actuality.

Whereas Aristotle limited the concept of the organ to specifically natural-functional contexts, thus embedding the techne of the organ within the order of nature (physis), romantic organology refashions this concept to move across discrete discursive domains. Although Aristotle denied that mind, as pure cognition, could embody or have an organ, thinkers in the eighteenth century entertained the possibility of the soul as an organ (e.g., in Soemmerring's On the Organ of the Soul [1796]), as a point enabling and limiting a series of reproductive and functional movements rather than as a locus of pure mental representations. The organ becomes a mobile and labile concept moving within and across systemic orders: a term that binds, separates, or traverses discrete or often incompatible domains such as, in the case of Hölderlin, thought and being, mechanics and organics, freedom and necessity, or physis and techne (135). Weatherby shows through a series of sophisticated and erudite readings that the romantic organ is not limited to any specific context but designates a metacontextual regulator, or a node through which elements and contexts can be organized depending on any given functional task. For this reason, the organ acquires a distinctively nonbiological sense, or at least is not limited to biological contexts of inquiry.

The book draws on a vast canvas of primary sources, including texts by both canonical literary and philosophical authors and lesser-known figures in the history of science, to show how the organ becomes a central conceptual resource - rather than a ground or foundationof romantic system building. In the wake of Kant's attempt to keep metaphysical speculation within the bounds of reason-which would effectively put an end to metaphysics as a system - thinkers such as Hölderlin, Novalis, and Schelling draw on the conceptual history and metaphorical resonances of the organ to construct a new metaphysics that would open a horizon of effectiveness for intervention in historical, natural, and political contexts. Organology, as a strategic and locally inflected constructivism, opposes itself to the wholesale Kantian repudiation of metaphysical systems on the one hand, and to closed metaphysical systems imbued with a teleological finality on the other hand. The metaphysics of the organ occupies a middle ground between the absence of metaphysics as such and the postulation of a strong, totalizing metaphysics; organs can provide a certain normative force and can be analyzed as discrete objects - as figures of mediation-but they produce "fragile syntheses" (10), something "akin to metaphysical bricolage, using historically prepared tools and developmentally formed beings to form new unities with new generalities" (10). Romantic organology therefore signals a shift from the task of thinking as the attempt to gain a more accurate representation or picture of the world to a conception of thought as a form of techne, e.g., as the separating and binding of discrete parts with other parts, parts 
with wholes, and certain discursive domains with others (cosmology, physiology, poetry, statecraft).

One can discern three main strands in the overall project undertaken by Transplanting the Metaphysical Organ: a historical genealogy, or how the organ came to play a central role in the constitution of fields of knowledge and modes of practice from the late eighteenth century to the mid-nineteenth century; an analytical constellation, or the presentation of synchronic snapshots of discursive variants drawing attention to the inflections of each specific organological project; and, finally, an engaged practice, or an attempt to frame the organ as a possible conceptual resource in the uncertain struggles of the present. As Weatherby notes, organology, or the proliferation of discourses in which the organ becomes a facilitator of metaphysical operations, emerges in a period when discursive stabilization has not yet occurred. The semantic and conceptual flexibility surrounding the organ renders it protean, able to adapt itself to different functional, philosophical, political, or poetic contexts. Thus Hegel can be both a thinker that repudiates organology as a whole in the Phenomenology of Spirit inasmuch as his system aims at an overarching totalizing metaphysics (29), and yet, he integrates organological insights into certain key operations of this system-for example, in the notion of the concept (der Begriff) as an "organon" of metaphysics (286).

Weatherby discovers this hitherto unexplored paradigm of metaphysical plasticity at work in an astonishing number of thinkers, poets, and scientists. The tripartite structure of his book—“Toward Organology," "Romantic Organology," "After Organology"—-suggests that organology takes on its most paradigmatic form in the romantic period, where "romantic" is understood more as a discursive constellation than in a strictly literary sense (neither Hölderlin, nor Hegel, nor Goethe could be considered romantic authors according to most customary definitions of romanticism, although aspects of some of their writings engage with "romantic organology"). Weatherby draws attention to the fact that organological metaphysics also has an important afterlife (e.g., in Marx) and continues to resonate with strands of contemporary metaphysical and political theory (e.g., with Bernard Stiegler's technics).

Focusing on the local instances of organological operativity in texts by authors from Leibniz to Marx permits Weatherby to creatively rethink their perspectives in novel ways. Hölderlin becomes a foundational thinker of romantic organology inasmuch as his metaphysics is constantly resolving and generating contradictions, ultimately giving a conceptual justification for a "radical metapolitics, a theoretical or spectatorial Jacobinism" (170). Schelling's philosophy of art does not make visible a metaphysics of "the order of things" (205), but conveys a world made of "synthetic organs" inasmuch as "the 'real' is always a series of syntheses, and it is only in the vicissitudes and apparent finalities of these syntheses that we encounter history and nature" (205). Novalis represents the most "robust" form of Romantic organology - which Weatherby calls transcendental realism-in which there is an essential "hole in the graph of the universe" (234). Novalis posits this discursively produced nothingness as the structural condition of a plastic, self-organizing form of politics that is always modifying its institutions in the face of concrete historical challenges. Weatherby, in a brilliant coda to his capacious discursive appetite, shows how the most fundamental contours of this organological field-one in which representation becomes intervention, in which material reality is saturated with the dual modalities of possibility and necessity - manifests 
itself in the works of Karl Marx. The culmination of the book in an analysis of the writings of Marx is absolutely appropriate, since, ultimately, organological metaphysical operations aim to respond in a flexible manner to the contingencies of history itself. Metaphysics is no longer "beyond" history, or an order prior to history, but a concrete engagement with history.

Given the density of its thought, the breadth and depth of its historical perspective, and the scope of its ambition, this book should, by all rights, become a benchmark not just in the study of romanticism, but a model for what a rigorously historical and intellectually daring mode of critical practice can accomplish. The prioritization of the local operations of discursive action-for example, when Weatherby focuses on the multiplicity of Schelling's various syntheses as opposed to Schelling's purported overarching systemic goal to uncover the unity of the real and the ideal—produces readings that often contravene accepted wisdom about these thinkers. In this reader's opinion, precisely this facet of Weatherby's work makes his own intervention, which is indeed the discovery of an "unexpected Romanticism" (352), all the more vital.

GABRIEl Trop

University of North Carolina, Chapel Hill 